\section{English in Brazil: Insights from the Analysis of Language Policies, Internationalization Programs and the CLIL Approach}

\author{
Kyria Finardi \\ Department of Languages, Culture and Education, Federal University of Espirito Santo \\ Av. Fernando Ferrari, 514, Vitória - ES - CEP 29075-910, Brazil \\ Tel: 55-2799-299-0058Ｅ-mail: kyria.finardi@gmail.com
}

Roberta Leão

Federal University of Espirito Santo

Av. Fernando Ferrari, 514, Vitória - ES - CEP 29075-910, Brazil

Livia Melina Pinheiro

Federal University of Espirito Santo

Av. Fernando Ferrari, 514, Vitória - ES - CEP 29075-910, Brazil

Received: December 14, 2015 Accepted: March 5, 2016 Published: March 7, 2016

doi:10.5296/elr.v2i1.9150 URL: http://dx.doi.org/10.5296/elr.v2i1.9150

\begin{abstract}
The paper proposes a reflection on the role of English in the globalized world and its teaching/learning in Brazil. With that aim, the study reviews language policies and internationalization programs in Brazil regarding the role of foreign languages in general and of English in particular. The theoretical framework includes a review of an English language teaching (ELT) approach used mainly in Europe, as a result of globalization and internationalization, the Content and Language Integrated Approach (CLIL). In order to support this reflection, a case study was carried out to examine pre-service English teachers' beliefs on the use of CLIL in Brazil. The results of study show that pre-service English teachers understand the importance of the CLIL approach though they are aware of the various
\end{abstract}


obstacles to its implementation in that context. The study suggests a review of language policies in Brazil so as to ensure a convergence between them and internationalization policies and approaches, at all levels of education. Regarding the ELT approach analyzed, the study concludes that despite the difficulties associated with the implementation of CLIL in Brazil, it represents a relevant alternative in that context.

Keywords: English language teaching (ELT), Content and Language Integrated Learning (CLIL), Language policies, Internationalization, Brazil

\section{Introduction}

In the globalized world we live in, English and the internet provide access to information and the possibility to interact on both local and global scales (Finardi, Prebianca, \& Momm, 2013). Globalization and information and communication technologies (ICTs) have erased geographical and temporal distances between people and changed the way we use, teach and learn foreign languages (Finardi \& Porcino, 2014). In this scenario, the English language has a leading role as it became the language of the internet, business, diplomatic relations, academic publications and international exchanges. Because of the role of English and the internet in the globalized world, Finardi, Prebianca and Momm (2013) claim that some knowledge of English and digital literacy are necessary skills to exercise a global citizenship.

In this scenario, the teaching/learning of foreign languages (L2) has a very important role in the 1) maintenance of national cohesion and international peace (e.g. Finardi; Csillagh,2016), 2) expansion of access to information (e.g. Finardi; Prebianca; Momm, 2013; Finardi; Tyler, 2015), 3) education for life and for the social inclusion of the diversity (e.g. Finardi; Csillagh,2016; Ortiz; Finardi, 2015; Finardi \& Archanjo, 2015) and in the 4) fight against negative effects of globalization such as the commodification of education (e.g.: Porcino \& Finardi, 2014; Finardi, 2014).

Regarding the commodification of education, sometimes associated with the internationalization of education, defined by Knight (2008) as the integration of an international dimension in the mission, function or product of higher education, Vavrus and Pekol (2015) claim that the internationalization of education cannot be separated from globalization and coincides with neoliberal policies and the decline of financial aid to universities forcing them to look elsewhere for financial support.

As a result of the internationalization of education universities are rethinking their mission and strategies as well as the approaches used to achieve their goals (Shin \& Teichler, 2014). Among the approaches used to boost internationalization is the Content and Language Integrated (CLIL) approach used mainly in Europe to teach different contents in English as a way to increase multilingualism and attract foreign academics of different parts of the world to European universities.

As an international language, English is the most spoken L2 today, though only $25 \%$ of English speakers are native speakers, the other $75 \%$ of which are non-native speakers (Finardi, 2014). These numbers have changed the way English is used, taught and learned in the world (for example Graddol, 2006) and in Brazil (for example, Finardi, \& Ferrari, 2008). Because English and technologies can increase access to global discourses, Leão and Finardi (in press) suggest 
that policies aimed at social inclusion are proposed to allow the positive effects of this access to become universal.

The decisions that supposedly reflect the interests of a society in relation to languages are embodied in language policies (LP), defined by Rajagopalan (2013, p. 21, our translation) as "the art of leading discussions around specific languages that matter to a group of people". Language policies problematize social issues that Rojo (2013, p. 68, our translation) describes as "...linguistic conflicts of borders, teaching and learning languages, teacher training, impacts of new technologies...".

The study of LP in Brazil is recent and finds much resistance due to the different importance given to different languages (Pinheiro \& Finardi, in press) as in the case of the status of English in relation to other foreign languages. According to Finardi and Archanjo (2015), English has the status of any other foreign language in basic education. As will be shown in the review of language policies in that country, one foreign language must be offered from 5 th grade on and though the school community can select the language to be taught, the choice is usually English, making it difficult to include other foreign languages in the Brazilian curricula for basic education.

As a way to improve general knowledge of English in Brazil and also stimulate multi/plurilinguism, Finardi (2014) suggests the teaching of English as an international language there so as to make room in the curriculum for the inclusion of other foreign languages. Finardi (2014) defines international language as the one which is used by native and non-native speakers in national and transnational contexts and whose focus is on its function rather than on the context where it is used/learned.

Given the role of English in the world and in Brazil today, the present study proposes a reflection on the status of English in language policies, internationalization programs and ELT methodologies in that country. So as to foreground the reflection, a study case was carried out to analyze pre-service English teachers' beliefs on the use of an approach to ELT that is still insipient in Brazil, namely, the Content and Language Integrated Learning (CLIL) approach. With that aim, the literature is reviewed in what follows and the study case is described right after it.

\section{Literature Review}

Despite common belief that Brazil is a monolingual country, it is in fact a multilingual country with dozens of immigrant and indigenous languages spread in many communities where Portuguese is not the mother tongue. As pointed out by Leffa (2013), Brazilians must recognize and preserve this multilingualism fighting against the omission and discrimination towards linguistic minorities through the reflection on and elaboration of language policies that promote understanding and tolerance among cultures, languages and identities. Leffa (2013) also alerts to the danger of linguistic isolation in Brazil, the only country in Latin America whose national language is Portuguese and where Brazilians face many challenges to learn foreign languages, be them the language of their parents (heritage languages) of their neighbors (Spanish) or the international language (English). In a country with over 200 million people, this represents a huge challenge for language policies and education in Brazil. 


\section{NI Macrothink}

Lagares (2013, p. 185) claims that the teaching of foreign languages in Brazil was sometimes treated as an extracurricular component being delegated to outsourced private language institutes that reinforced the belief foreign languages cannot be learned fluently in schools ( $\mathrm{p}$. 186). This belief is supported by authors (for example Tilio, 2014) who suggest that just as the public school does not form mathematicians or historians (to give but two examples), it does not have the responsibility to form fluent speakers of foreign languages either. Finardi, Prebianca and Momm (2013) and Finardi (2014) disagree with this view of the responsibility of Brazilian public schools based on the assumption that some knowledge of English is necessary to build a global citizenship and public education must guarantee the teaching of English with quality. Gimenez (2013) and Finardi (2014) go a step forward to suggest that the lack of responsibility of public schools to form fluent speakers of English increases the social gap of those who can afford to study English as a foreign language in private institutes and those who cannot.

Regarding the role of English in Brazilian language policies, Finardi and Archanjo (2015) show that English has the status of an optional foreign language in basic education where one foreign language must be offered after 5th grade and though the language offered is usually English, the choice of the language is made by each school community. In higher education the scenario changes and English has the status of an international language as can be seen by the investment in English when compared to the investment in other languages in internationalization programs. The authors suggest that language policies should be reviewed in Brazil so as to converge in all educational levels. The authors also suggest that the reflection on language policies is very important now, when Brazil implements internationalization programs such as the Science Program without Borders (SwB), the Language without Borders (LwB) and the English without Borders (EwB) programs.

The Brazilian government funded program Science without Borders (SwB) aims at developing the internationalization of the scientific and technological fields by offering scholarships for Brazilian university students to go abroad. Another important Brazilian government funded program is the English without Borders $(\mathrm{EwB})$ which was created to improve the overall level of proficiency in English of Brazilian university students so that they could join the SwB and other internationalization programs. The EwB offers three actions for free, namely 1- the application of proficiency tests, the TOEFL ITP test; 2- an online English course - My English Online (MEO); 3- and traditional face-to-face English classes to part of the academic community. Whereas the first two actions are available for all university students, the last one is available to a small percentage (around $3 \%$ ) of the university community.

The MEO course was analyzed by Pinheiro and Finardi, (2014) and Finardi, Prebianca, Schmitt and Andrade, (2014) who concluded that though the course offers a relevant contribution for the learning of English, it is not sufficient to guarantee its learning by itself once it does not offer the possibility to interact in English and so it is difficult to develop productive skills such as speaking and writing in the course, once no feedback is given on these skills. These authors concluded that the MEO course could be more relevant to the development of English proficiency if it were used in tandem with other courses which offered feedback to writing and speaking skills. The problem is that the face-to-face classesof the EwB program, offered in language centers (Nuclis) created at the Brazilian universities have a 
limited number of teachers and courses available and so only about $3 \%$ of the academic population can take these courses.

Regarding the role of English in internationalization and English language teaching (ELT) methodologies, although the Content and Language Integrated Learning (CLIL) approach to ELT has become very popular in the northern hemisphere, used mainly in Europe and in Canada as a way to promote multilingualism in basic education and internationalization in higher education, in Brazil the use of this approach is still in its infancy (Alencar, 2016; Finardi; Silveira; Alencar, in press; Finardi; Fadini; Alencar; Porcino, in press) and faces many challenges. So as to reflect about possibilities and limitations of implementing this approach in Brazil a case study was carried out and will be described in what follows.

\section{Methodology}

In order to support the reflection proposed in this paper, a case study was carried out to analyze pre-service teachers' beliefs on the use of CLIL in Brazil. The study was carried out in the English Teaching Degree Course of the Federal University of Espirito Santo (UFES) in 2014. Data collection included about 30 hours of class observation in the course of Supervised Internship I and questionnaires and interviews to the students and the professor in that course. The Supervised Internship Practicum is the course where students (pre-service teachers) do their Practicum in regular public schools. The study is qualitative (Dornyei, 2007), and data were collected through a questionnaire (Appendix 1) administered to 13 students (pre-service teachers) of the course investigated who were then enrolled in the Practicum Course and through an ethnographic observation of the classes in this course during the second term of 2014. The questionnaire was conducted in their native language, so the answers (Appendix 2) are in Portuguese but were translated to English for analysis. The questionnaire contained 3 questions, the first one asking about the role of the English teacher, the second one about students' view on critical approaches to ELT and the last one about the CLIL approach. This paper addresses only the answers to the first and third questions regarding the role of the English teacher and pre-service teachers' beliefs on CLIL.

\subsection{Context}

The English Teaching Degree Course analyzed lasts 8 terms (semesters) divided in to 55 courses concentrated in subject areas such as literature, linguistics, applied linguistics, education, psychology, socio-historical studies, sociology and philosophy. There is no specific course dedicated to the instruction and discussion of critical approaches such as CLIL. The supervised internship (Practicum) course is offered in the last two semesters and comprises the discussion of practices and theoretical assumptions about the teaching of English as a foreign language in Brazil.

This Practicum course has 200 hours divided in 80 hours dedicated for theory and 120 hours dedicated for practice, usually involving the supervised teaching in public schools. Students prepare class plans and projects to use in the schools where they will do their practicum. During the Practicum classes students were introduced to some teaching methods including CLIL and were asked to elaborate lesson plans using the CLIL approach. Four classes were dedicated in the Practicum course to help pre-service teachers prepare these class plans. 
Pre-service teachers in this course should also observe classes in public schools and report their experiences during the classes in the Practicum course. In the end of the Practicum course students should present a written report containing the description of their experience and their reflections during the supervised teaching course.

\section{Analysis}

The analysis of the questionnaire administered to the pre-service teachers shows that pre-service teachers do not agree on what should be the role of an English teacher. Results show that some of them view teachers as "holders" of knowledge who should "deliver" it to students as shown in the excerpts below:

"Be a colonizer. The system maintenance of the rulling power. Keep tight reins." P.S.T. 2

"To apply contents successfully. P.S.T. 4

"Assist students in understanding short texts, reading, communication, listening. Make students able to communicate through English. P.S.T. 7

Pre-service teachers 4 and 7 state that the role of the teacher is related to capacity to make students understand the content using the four skills to communicate while pre-service teacher 2 believes that English teachers emphasize the idea that people have to learn the language of the colonizing nation and they do not have autonomy to choose or give opinion about this issue, probably this future teacher is referring to the fact that most people do not have a choice to learn English.

Nonetheless teachers do not need necessarily to ignore the native or even the foreign culture to teach the English language, if they focus in the contents rather than on the forms of the language, as it is suggested in the CLIL approach. The following excerpts show that some students believe that one of the roles of the English teacher is to teach cultures but not necessarily contents outside the language.

"In addition to teaching the language, teach the culture related to the language and the new role of the student in the globalized world." P.S.T. 5

"Open a range of options tostudents teaching them about other 'worlds'." P.S.T 6

"Nowadays it is rethinking culture and language, but it could be to transmit knowledge through language". P.S.T. 9

These three pre-service teachers believe that the role of language teachers is to teach about the language and the culture engaging students in reflections on the globalized world. It is possible to infer through the speech of pre-service teacher 6 that the language is seen as manner to expand knowledge about the other and this information about the other may help in the construction of students as global citizens. The answer of pre-service teacher 9 is more connected to the idea of CLIL, for he believes that teaching a language could be done by exchanging knowledge through that language, and this same participant believes that CLIL is a good approachbecause it focuses on teaching language through a topic and not through grammar as can be seen in the excerpt below:

"Yes, I think it is possible, because I think it is better to address a specific subject using English than explain English via grammar." P.S.T. 9 
However results of the questionnaire administered to analyze pre-service teachers' beliefs on CLIL show that most participants understand the potential of CLIL but see many barriers to its implementation in Brazil. The pre-service teachers who work as language instructors in private language institutes claim that it would be difficult to use CLIL there because they do not have autonomy to choose activities, materials or methods and usually have to teach from pre-set materials and contents, as shown in the answers of pre-service teachers 4, 7 and 10.

"No. My workplace has a pre-defined approach, and so, defined content. There are few opportunities for extra activities due to restricted hours." P.S.T. 7

"I do not use CLIL, because I teach in a private English course and there is no space for other approaches that do not have to do with the pre-established one by the school." P.S.T. 10

"No, because the school shapes us to use textbooks and we have to follow them" P.S.T. 4

Most of the pre-service teachers who answered the questionnaire see CLIL as a possibility to teach beyond grammar, increasing interdisciplinarity and contextualizing the teaching of both contents and that of the language as shown in excerpts from pre-service teachers 1, 3 and 6:

"Yes, CLIL is an approach that inserts the English in the reality of the student, removing the mechanical focus of grammar." P.S.T. 1

"Yes, I would use CLIL because it is an approach that includes not only the language, but a great interdisciplinarity too." P.S.T. 3

"Yes, students would learn much more than grammar in CLIL. And they would see learning results. They would realize what they are learning." P.S.T. 6

Pre-service teacher 2 answered in Question 1 that an English teacher just reinforces the idea that there is a colonizingnation and people need to learn their language and acquire they habits, and now in Question 3 the same participant agrees with the use of CLIL, perhaps as a way to break the view that English language and culture have to be taught in English classes, in spite of the decision not to become a teacher in the future, as shown in the following excerpt:

"I will not teach English when I graduate. But such a contextual approach (CLIL) seems to be a very interesting way to teach English. I would use it if I were a teacher. It breaks the normative and boring paradigm that language teaching is about teaching grammar in the foreign language." P.S.T. 2

As we can be seen in the speech of pre-service teachers above, in general participants in the study believe that CLIL may be a relevant approach to teach English though they recognize some difficulties for its implementation in Brazil which are associated mostly with the lack of autonomy of teachers working in the private sector.

The analysis of the class observations during the Supervised Practicum Course suggests that the professor of this course attempts to deconstruct some beliefs such as: public schools are disorganized; it is not possible to work all the skills of the target language in the classroom; there is a lack of resources to enable language teaching/learning; there is no interest to learn English in Brazil; the English teaching has to follow a program of pre-established contents. The professor seems to believe that the CLIL approach may be a solution to overcome some of these challenges. While discussing this methodology with students, the professor mentioned that if CLIL were used in public schools in collaboration with teachers of other disciplines, the number of hours dedicated to English teaching would increase. Furthermore, the professor 
commented that CLIL is a form of fighting against the teaching of foreign languages with a focus on grammar and vocabulary in the target language. One of the pre-service students in the course commented that the preparation of material for the CLIL approach requires more time, effort and knowledge from the English teacher, and the professor answered that it was true but it was also an opportunity for English teachers to develop their autonomy in the elaboration of teaching materials and at the same time an opportunity to increase the collaboration between language teachers and contents teachers thus fostering interdisciplinarity. As it is, the analysis of the class observations of the Practicum Course shows that the professor sees CLIL as a wayof changing some teaching practices and beliefs about English teaching in Brazil.

\section{Conclusion}

The present study offered a reflection on the role of English in the globalized world and its teaching in Brazil. With that aim, the study reviewed language policies and internationalization programs in Brazil regarding the role of foreign languages in general and of English in particular. The theoretical framework included a review of an English language teaching (ELT) approach used mainly in Europe, as a result of globalization and internationalization, the Content and Language Integrated Approach (CLIL). In order to support this reflection, a case study was carried out to examine pre-service English teachers' beliefs on the use of CLIL in Brazil. The results of study showed that pre-service English teachers think that the CLIL approach is a relevant option for Brazil though its implementation would face some barriers such as with the lack of autonomy of teachers to select contents and the lack of investment on teachers to plan materials. Regarding the use of CLIL in Brazil, the study concludes that despite the difficulties associated with the implementation of this approach, it represents a relevant alternative to change teachers' practices and beliefs about English language teaching in Brazil.

\section{References}

Alencar, J. G. (2016). Abordagem de Ensino de Língua Inglesa por meio de Conteúdos e Formação de Professores: Apropriações, Possibilidades e Limitações. Master's dissertation. (Master's in Education). Universidade Federal do Espirito Santo. Forthcoming.

Dorney, Z. (2007). Research methods in applied linguistics: Quantitative, qualitative and mixed methodologies. Oxford: Oxford University Press.

Finardi, K. (In press). Aspectos da ensinagem crítica de inglês na formação e internacionalização da educação no Brasil contemporâneo: o papel das políticas linguísticas, metodologias e tecnologias. In: A pesquisa em Educação e Linguagem. Book Organized by PPGE- UFES.

Finardi, K. (2014). The Slaughter of Kachru's Five Sacred Cows in Brazil: Affordances of the Use of English as an International Language. Studies in English Language Teaching, 2, 401-411.

Finardi, K., \& Archanjo, R. (2015). Reflections of Internationalization of Education in Brazil. In 2015 International Business and Education Conference, 2015, New York. 2015 International Business and Education Conference Proceedings (Volume 1, pp. 504-510). New York: Clute Institute. 
Finardi, K., \& Csillagh, V. (2016). Globalization and linguistic diversity in Switzerland: insights from the roles of national languages and English as a foreign language. In: S. Grucza; M. Olpińska; P. Romanowski. (Org.). Advances in Understanding Multilingualism. 1ed.Warsaw: Peter Lang GmbH, International Academic Publishers, Frankfurt am Main, 2016, v. 24, p. 41-56.

Finardi, K., \& Ferrari, L. (2008). Reflecting on the English(es) taught in Brazil. Crop (FFLCH/USP), 13, 205-214.

Finardi, K., \& Porcino, M. C. (2014). Globalization and Internationalization in ELT: Methodology, Technology and Language Policy at a Crossroad in Brazil. In: International Conference of Education, Research and Innovation, 2014, Sevilha (Volume 1, pp. 1-11). ICERI2014 Proceedings. Madri: IATED.

Finardi, K., Prebianca, G. V. V., Schmitt, J., \& Andrade, D. F. (2014). Technology, English Language Teaching and Internationalization at a Crossroad: Insights from the Analysis of a Virtual Learning Environment in Brazil. In: International Conference of Education, Research and Innovation, 2014, Sevilha (Volume 1, pp. 1-12). ICERI2014 Proceedings. Madri: IATED. Finardi, K., Fadini, K., Alencar, J. G., Porcino, M. C. (In press). Formação de professores de inglês para o Brasil do século XXI: Refletindo sobre as crenças de futuros professores sobre o uso de tecnologia e da metodologia CLIL no ensino de inglês. Revista Signótica.

Finardi, K., Prebianca, G., \& Momm, C. (2013). Tecnologia na Educação: o caso da Internet e do Inglês como Linguagens de Inclusão. RevistaCadernos do IL, 46, 193-208.

Finardi, K., Silveira, N., \& Alencar, J. G. (In press). First Aid and Waves in English. Eletronic Journal of Science Education (EJSE).

Finardi, K., \& Tyler, J. (2015). The Role of English and Technology in the Internationalization of Education: Insights from the Analysis of MOOCs. In: 7th International Conference on Education and New Learning Technologies, 2015, Barcelona. Edulearn15 Proceedings. (Volume 1, pp. 11-18) Barcelona: IATED.

Gimenez, T. (2013). A Ausência de Políticas Para o Ensino de Língua Inglesa nos Anos Iniciais de Escolarização no Brasil. In: Nicolaides, C.; Silva, K.A.; Tílio, R.; Rocha, C.H. (Orgs.) Política e Políticas Linguísticas. Campinas: Pontes Editores.

Graddol, D. (2006). English Next: Why global English may mean the end of "English as a foreign language". The English Company (UK) Ltd. British Council (p. 132). Retrieved from http://www.britishcouncil.org/learning-research-english-next.pdf

Knight, J. (2008). The internationalization of higher education: Complexities and realities. In D. Teferra \& J. Knight (Eds.), Higher education in Africa: The international dimension (pp. 143). Boston: Boston College Center for International Higher Education.

Lagares, X. C. (2013). Ensino do espanhol no Brasil: uma (complexa) questão de política linguística. In C. Nicolaides, K. A. Silva, R. Tílio, \& C. H. Rocha, (Orgs.) Política e Políticas Linguísticas (pp. 181-198). Campinas: Pontes Editores.

Leão, R., \& Finardi, K. (In press). Ensino de Inglês Como Língua Internacional e Abordagem CLIL: Reflexões de um Estudo de Caso. In: III Conel, Vitória. III Conel Proceedings. Vitória: PPGEL. 
Leffa, V. (2013). Prefácio. In C. Nicolaides, K. A. Silva, R. Tílio, C. H. Rocha, (Orgs.) Política e Políticas Linguísticas (pp. 7-10). Campinas: Pontes Editores.

My English Online. Retrieved November 13th, 2015, from http://www.myenglishonline.com.br

Ortiz, R. A., \& Finardi, K. (2015). Social Inclusion and CLIL: Evidence From La Roseraie. In International Conference on Education, Research and Innovation 2015, 2015, Sevilha. ICERI2015 Proceedings (Volume 1, pp. 7660-7666). Madri: Iated.

Pinheiro, L. M. S., \& Finardi, K. (2014). Políticas públicas de internacionalização e o papel do inglês: evidências dos programas CsF e IsF. In: II Conel, 2014, Vitória. II Conel Proceedings (Volume 1, pp.76-78). Vitória: PPGEL.

Pinheiro, L. M .S., \& Finardi, K (In press). O Papel do Inglês nas Políticas Linguísticas e de Internacionalização. In: III Conel, Vitória. III Conel Proceedings. Vitória: PPGEL.

Rajagopalan, K. (2013). Política linguística: do que é que se trata, afinal? In C. Nicolaides, K. A. Silva, R. Tílio, \& C. H. Rocha (Orgs.) Política e Políticas Linguísticas. Campinas: Pontes Editores.

Rojo, R. (2013). Caminhos para a LA: Política linguística, política e globalização. In C. Nicolaides, K. A. Silva, R. Tílio, \& C. H. Rocha (Orgs.) Política e Políticas Linguísticas. Campinas: Pontes Editores.

Shin, J. C., \& Teichler, U. (2014). The Future of The Post-Massified University at the Crossroads. Restructuring Systems and Functions. Springer. http://dx.doi.org/10.1007/978-3-319-01523-1

Tilio, R. (2014). Língua Estrangeira Moderna na Escola Pública: possibilidades e desafios. $\begin{array}{llll}\text { Educação \& Realidade, Porto Alegre, } & 39(3), & 925-944 .\end{array}$ http://dx.doi.org/10.1590/S2175-62362014000300016

Vavrus, F., \& Pekol, A. (2015). Critical Internationalization: Moving from Theory to Practice. FIRE: Forum for International Research in Education, 2(2).

\section{Appendices}

Appendix 1. Questionnaire for students. (Translations to the appendices are right after them). 1. Para você qual é a principal função do professor de inglês?

What is the role of the English teacher, in your opinion?

2. O que você entende por abordagens críticas de ensino de língua estrangeira? Você acha possível usar abordagens críticas no ensino público regular? Fundamente sua resposta.

What do you understand as critical teaching approaches? Do you think it is possible to use critical approaches in the public regular school education? Justify your answer.

3. Você utilizaria a abordagem CLIL em suas aulas? Justifque.

Would you use the CLIL approach? Justify your answer. 


\section{Macrothink \\ Education and Linguistics Research \\ ISSN 2377-1356 \\ 2016, Vol. 2, No. 1}

Appendix 2. Answers of pre-service teachers.

\section{Pre-service Teacher 1}

Question 1: Ajudar aos alunos a adquirirem conhecimentos em língua inglesa através de metodologias diversas.

Question 2: Apesar da dificuldade que o professor enfrenta ao tentar implantar algo diferente, é possível usar a abordagem crítica para que as aulas façam sentido para os alunos.

Question 3: Sim, pois é uma abordagem que insere o inglês na realidade do aluno, tirando o foco mecânico da gramática.

\section{Pre-service Teacher 2}

Question 1: Ser colonizador. A manutenção do sistema, do poder vigente. Manter as rédeas apertadas.

Question 2: Utilizando o contexto. Utilizando os diversos temas para o ensino. E acho que é válido as abordagens críticas e ensinar além da normativa.

Question 3: Não darei aula. Mas tal abordagem contextual parece ser uma forma bem interessante. Daria se fosse dar aula. Quebra o paradigma normativo e chato que é só passar gramática.

\section{Pre-service Teacher 3}

Question 1: Fomentar a busca do aluno para com a língua e seus aspectos.

Question 2: Sim. A abordagem crítica busca a discussão a cerca de assuntos sobre a língua e seus aspectos e também sobre outros assuntos pertinentes que englobam a língua estrangeira. $\mathrm{O}$ ensino público regular é como qualquer outro espaço onde a língua é trabalhada.

Question 3: Sim, porque é uma abordagem que abrange não só a língua, mas uma grande interdisciplinaridade em seus aspectos.

\section{Pre-service Teacher 4}

Question 1: Conseguir passar o conteúdo utilizado com sucesso.

Question 2: Acho meio difícil utilizar abordagens críticas no ensino público regular, pois muitas vezes os alunos muitas vezes não se interessam por discussões.

Question 3: Não, pois a escola nos molda para usar os livros e temos que segui-los.

\section{Pre-service Teacher 5}

Question 1: Além de ensinar a língua, ensinar as culturas relacionadas a língua e o novo papel do aluno no mundo globalizado.

Question 2: Creio que estamos caminhando a passos lentos à uma educação crítica. Mas é importante ensinar os alunos a pensarem como cidadão.

Question 3: Sim, na verdade, creio que já fazemos o uso da abordagem crítica sem saber. É importante que relacionemos o tema abordado com a realidade dos alunos

\section{Pre-service Teacher 6}

Question 1: Abrir o leque de opções dos alunos ensinando-lhes sobre outros "mundos".

Question 2: Sim, claro. Os alunos devem saber o porquê deles estarem estudando o que estão estudando e as consequência desse ato. 
Question 3: Sim, alunos iriam aprender muito mais que a gramática. E iriam ver os resultados do aprendizado. Teriam noção do que estão aprendendo.

\section{Pre-service Teacher 7}

Question 1: Auxiliar o aluno na compreensão de pequenos textos, leitura, comunicação, escuta. Tornar o aluno capaz de se comunicar através do inglês.

Question 2: Sim, o inglês pode ser uma grande ferramenta na pesquisa de notícias e matérias para discussão na sala de aula. A partir do inglês o leque de opções é maior.

Question 3: Não. Meu local de trabalho possui abordagem pré-definida, assim conteúdo definido. São poucas oportunidades para atividades extras devido ao horário restrito.

\section{Pre-service Teacher 8}

Question 1: Instruir o aluno, possibilitar a compreensão de um novo idioma.

Question 2: Entendo sobre as que aprendi na sala de aula, acho o currículo imposto pelo Estado um problema que não impossibilita o uso, porém atrapalha.

Question 3: Utilizaria, pois relacionar-se com a vida do aluno é uma maneira não apenas de engajá-lo como de fazê-lo extrair o máximo de todos os conteúdos.

\section{Pre-service Teacher 9}

Question 1: Hoje é repensar cultura e língua, mas poderia ser repassar conhecimentos por meio da língua.

Question 2: Abordagens críticas fazem os alunos pensarem sobre o tema que estudaram e desenvolverem sua opinião. Acho possível sim, dentro do currículo proposto.

Question 3: Se possível, sim, pois acho melhor abordar um tema específico utilizando o inglês, do que explicar inglês via gramática.

\section{Pre-service Teacher 10}

Question 1: Ensinar a língua e questões relacionadas à ela, além de conteúdos gramaticais e técnicas.

Question 2: Fazer o aluno compreender não só a língua, mas também sobre a língua. É possível, pois há mais espaço e liberdade (autonomia) para o professor planejar suas aulas no ensino regular do que em cursos particulares.

Question 3: Não utilizo, pois leciono em um curso particular de inglês e não há espaço para outras abordagens que não a já pré-estabelecida pela escola.

\section{Pre-service Teacher 11}

Question 1: Contribuir para a formação do aluno enquanto indivíduo através do ensino da língua.

Question 2: Acho que seria possível desde que as aulas fossem bem planejadas e estruturadas. Question 3: Sim. Acho perfeitamente possível integrar conteúdo e gramática.

\section{Pre-service Teacher 12}

Question 1: Ajudar o aluno a perceber o papel transformativo da língua.

Question 2: Em branco.

Question 3: Sim, porque assim eu poderia ajudar os alunos a perceberem que a língua não está desassociada do mundo. 


\section{Macrothink \\ Education and Linguistics Research \\ ISSN 2377-1356 \\ 2016, Vol. 2, No. 1}

\section{Pre-service Teacher 13}

Question 1: Conduzir o aluno ao interesse pelo conhecimento. Despertar desejo de aprender e ensinar autonomia.

Question 2: Acho possível e acredito que seja o lugar ideal para aplicação e experimentação, visando sempre adequar as diferentes abordagens a cada grupo específico e suas necessidades e desejos.

Question 3: Sim. Eu tento ao máximo aplicar o pouco que eu tenho de experiência com essa abordagem. Principalmente porque ela torna o ensino de línguas mais contextualizado a realidade dos alunos.

Translation to the Appendices

\section{Participant 1}

Question 1: Help students acquire English language skills through a variety of methodologies.

Question 2: Despite the difficulty that teachers face when trying to implement something different, it is possible to use a critical approach to make the classes more relevant for students. Question 3: Yes, it is an approach that inserts the English in the reality of the student, removing the mechanical focus on grammar.

\section{Participant 2}

Question 1: Be a colonizer. The system maintenance of the ruling power. Keep tight reins.

Question 2: Using the context. Using various topics for teaching. And I think that it is worth, the critical approaches and teaching beyond the rules.

Question 3: I will not teach. But such a contextualized approach seems to be a very interesting way. I would use it if I were a teacher. It breaks the normative and boring paradigm that is just going through grammar.

\section{Participant 3}

Question 1: Encourage the searching of students about the language and its aspects.

Question 2: Yes. A critical approach searches for discussion of issues about language and its aspects and also about other relevant issues that include the foreign language. Regular public education is like any other space where the language is explored.

Question 3: Yes, because it is an approach that includes not only the language, but a great interdisciplinarity in its aspects.

\section{Participant 4}

Question 1: To apply contents successfully.

Question 2: I think it is hard to use critical approaches in the regular public system of teaching, because students usually are not interesting in discussions.

Question 3: No, because the school shapes us to use textbooks and we have to follow them.

\section{Participant 5}

Question 1: In addition to teaching the language, teaching the culture related to the language and the new role of the student in the globalized world.

Question 2: I believe that we are moving in a slow pace to a critical education. But it is important to teach students to think as a citizen. 


\section{Macrothink}

Question 3: Yeah, actually, I think we are already using the critical approach without knowing it. It is important to relate the topic covered with the reality of students.

\section{Participant 6}

Question 1: It opens a range of options for the students by teaching them about other "worlds". Question 2: Yes of course. Students should know why they are studying what they are studying and the consequences of that.

Question 3: Yes, students would learn much more than grammar. And they would see learning results. They would realize what they are learning.

\section{Participant 7}

Question 1: Assist students in understanding short texts, reading, communication, listening. Make students able to communicate through English.

Question 2: Yes, English can be a great tool for research news and materials for discussion in the classroom. From the English the range of options is bigger.

Question 3: No. My workplace has a pre-defined approach, and so, defined content. There are few opportunities for extra activities due to restricted hours.

\section{Participant 8}

Question 1: Instruct the student, and enable the understanding of a new language.

Question 2: I do understand about what I learned in the classroom, I think the State-imposed curriculum is a problem that does not make it impossible, but it makes it difficult.

Question 3: I would use it, because the relation with students' life is a way to not only engage them, but also to make them to get the maximum of all contents.

\section{Participant 9}

Question 1: Nowadays it is rethinking culture and language, but it could be to transmit knowledge through language.

Question 2: Critical approaches make students think about the topic studied and develop their opinion. I think it is possible, within the proposed curriculum.

Question 3: Yes, I think it is possible, because I think it is better to address a specific subject using English than explain English via grammar.

\section{Participant 10}

Question 1: Teach the language and issues related to it in addition to grammatical contents and techniques.

Question 2: Make students understand not only the language, but also about the language. It is possible because there are spaces and freedom (autonomy) for teachers to plan their classes in the regular teaching more than in private courses.

Question 3: I do not use because I teach in a particular course of English and there is no space for other approaches that do not have to do with the pre-established ones by the school.

\section{Participant 11}

Question 1: Contribute to the formation of the student as an individual through language teaching.

Question 2: I think it would be possible since the lessons were well planned and structured. 
Question 3: Yes. I think it is perfectly possible to integrate content and grammar.

\section{Participant 12}

Question 1: Help students to realize the transformative role of language.

Question 2: Question not answered.

Question 3: Yes, because then I could help students realize that language is not disassociated from the world.

\section{Participant 13}

Question 1: Lead the student to have interest in knowledge. And arise in them, the desire to learn and also to teach autonomy to them.

Question 2: I think it is possible and I believe it is the ideal place for application and experimentation, aiming to adequate the different approaches to each specific group and their needs and desires

Question 3: Yes. I tried to apply the maximum of a little I have experienced with this approach. Mainly because it makes language teaching more contextualized to the reality of students.

\section{Copyright Disclaimer}

Copyright reserved by the author(s).

This article is an open-access article distributed under the terms and conditions of the Creative Commons Attribution license (http://creativecommons.org/licenses/by/3.0/). 